\title{
Effect of Egyptian Rock Phosphate and Phosphate Dissolving Bacteria on Coriander Plant Growth and Yield
}

\author{
Salwa S.S. Awad Alla", Hanan M.H. Ali" and M.Y. Abou-Zeid"*, \\ *Horticulture Research Institute and ${ }^{* *}$ Soil, Water and \\ Environment Research Institute, Agricultural Research Centre, \\ Cairo, Egypt.
}

\begin{abstract}
7 HE PRESENT experiment was conducted in two successive seasons 2010/2011 and 2011/2012 to study the effect of Egyptian rock phosphate at the rates of $0,115,150$ and $190 \mathrm{~kg} / \mathrm{fed}$ and inoculation with phosphate dissolving bacteria (Bacillus megaterium var. phosphaticum) on growth, fruit yield and oil yield of coriander (Coriandrum sativum L.) as well as the effect of these treatments on the activity of rhizospheric soil microorganisms of coriander plants. The results showed that coriander plants were significantly responded to Egyptian rock phosphate (ERP) and phosphate dissolving bacteria (PDB) solely or together. ERP and/or inoculation with PDB increased the vegetative growth expressed as plant height, number of branches, fresh and dry weights of aerial parts of plant. Also it significantly increased fruit yield. This increase was parallel to the gradual increase in the rate of Egyptian rock phosphate from 0 to 150 $\mathrm{kg} / \mathrm{fed}$. The interaction between ERP and PDB gave the highest fruit yield, oil percentage, oil yield, with the highest Linalool content.The inoculation with phosphate dissolving bacteria (PDB) significantly increased dehydrogenase enzyme activity of coriander plants, it has been as a valid biomarker to indicate changes in total microbial activity due to soil management and increased gradually with increasing the rate of ERP up to $150 \mathrm{~kg} / \mathrm{fed}$.
\end{abstract}

Medicinal and aromatic plants (MAPs) play an important role in our daily life. That is, of course, because they contain safe and effective ingredients. The world now is giving natural products more attention, reducing the use of chemicals and pollutants, and its harmful side effects which dangerous diseases.

In the last few years the medicinal and aromatic plants gained a great importance, and the increment in exportation rates of these plant raised the national income US\$ (Hikal and Omar,1993).

Coriander, Coriandrum sativum L. belongs to the family Apiaceae (Umbelliferae) is one of the important MAPs which annually cultivated in about 10.000 feddans in Egypt.It used for improving taste and for the general benefit of digestive system, and is mainly used for spicing pickles, drinks and meat products. High amounts of the essential oil of coriander are used in cosmetics and perfume industry (Mahran,1967). 
Phosphorus (P) plays an important role in various metabolic processes. It is a constituent of nucleic acid phospholipids, DNA and NADP and most importantly A.T.P. It activates coenzymes for amino acids production used in protein synthesis and it is decomposes carbohydrate in photosynthesis, as well as involved in many other required metabolic processes for normal growth, such as photosynthesis, glycolysis, respiration, fatty acids synthesis. Moreover, P enhances seed germination and early growth, stimulates blooming, enhances bud set, aids in seed formation and hastens maturity (Espinnosa et al., 1993).

Natural rock phosphate contains, in addition to phosphorous, many of the micronutrients that are necessary for healthy plant growth and high productivity, Sastry et al. (1997) on Chrysanthemum cinerariaefolium, Haque and Lupmayi (1999) on Trifolium tembense, concluded that, phosphates is a natural, efficient and economical source of P fertilization. Grham and Timmer (1985) noticed that loss of $\mathrm{P}$ from super phosphate-amended soil was exponential where the release of $\mathrm{P}$ from rock phosphate-amended soil was linear. Also rock phosphate is chemically reactive and can be substituted in finely ground forms for manufactured fertilizers such as super phosphate (El-Sayed, 2006). In the same way, El- Sayed et al. (2009) on Tarragon (Artemisia dracunculus, L.). found that, growth character in terms of plant height, fresh and dry weights were stimulated by Egyptian rock phosphate (ERP) fertilizer.

The naturally occurring soil bacteria that capable of stimulating plant growth named as Plant-Growth-Promoting-Rhizobacteria (PGPR) such as Baccillus spp. (Kloepper and Schorth, 1981). PGPR are able to exert a beneficial effect upon plant growth. Phosphate dissolving bacteria (PDB) are important for plant nutrition by increasing plant $\mathrm{P}$ uptake, where these bacteria are able to dissolve the precipitated phosphorus depends on its efficiency in producing inorganic, or organic acids and/or $\mathrm{CO}_{2}$. Therefore, the unavailable forms of phosphorus can be partially dissolved by PDB naturally occurring or inoculating into the soil (Zayed, 1998). Moreover, Chakrabotry et al., 2006 found that, B. megaterium from tea rhizosphore is able to produce IAA and thus it helps plant growth promotion. Regarding the interaction between phosphorus fertilizer and PDB, Ahmed et al. (2002) and Badran (2003) found that P fertilizer and PDB treatment led to higher nutrient concentrations in seed and an increment in seed yield of soybean and Lentil plants. Also, Mekhemar et al. (2007) stated that improvement of peanut yield could be achieved by the application of $16 \mathrm{~kg}$ $\mathrm{P}_{2} \mathrm{O}_{5} / \mathrm{fed}$ as rock phosphate in addition to the inoculation with Brady rhizobium + PDB) under sandy soil conditions.

For this reason, this investigation was conducted to determine the effect of Egyptian rock phosphate (ERP) as a source of phosphorus (natural fertilizer) and phosphate dissolving bacteria (PDB) on the growth, yield and oil production of coriander (Coriandrum sativum L.). 


\section{Materials and Methods}

This study was conducted at the experimental farm of medicinal and aromatic plants in El-Kanater El Khairia, Egypt during two successive seasons (2010/2011\&2011/2012).

The fruits of coriander (Coriandrum sativum L.) were obtained from the experimental farm of Faculty of Pharmacy, Cairo University. The fruits were sown on $5^{\text {th }}$ November in the field at a distance of $30 \mathrm{~cm}$ between hills and 60 $\mathrm{cm}$ between rows in both seasons.

The layout of this factorial experiment was a complete randomized blocks design, with three blocks (replicates) and 8 combinations of the two studied factors (2PDB X 4 ERP). Each plot contained 20 plants, the area of each plot was $\left(3 \times 1.2 \mathrm{~m}^{2}\right)$.

The treatments were:

- Control (without ERP or PDB).

- ERP $115 \mathrm{~kg} / \mathrm{fed}$.

- ERP $150 \mathrm{~kg} / \mathrm{fed}$.

- ERP $190 \mathrm{~kg} / \mathrm{fed}$.

- PDB

- ERP $115 \mathrm{~kg} / \mathrm{fed}+$ PDB.

- ERP $150 \mathrm{~kg} / \mathrm{fed}+\mathrm{PDB}$.

- ERP $190 \mathrm{~kg} / \mathrm{fed}+\mathrm{PDB}$

The plants were fertilized by $\mathrm{NK}$ at the recommended doses, using ammonium sulphate $(20.5 \% \mathrm{~N})$ and potassium sulphate $\left(48 \% \mathrm{~K}_{2} \mathrm{O}\right)$ in both seasons.

The fertilizers were added at two equal splits, after 45 and 75 days from sowing.

Egyptian rock phosphate (ERP, containing 20.5\% $\mathrm{P}_{2} \mathrm{O}_{5}$ ) was tested as a source of phosphorus. The ERP was applied at the rates of $0,115 \mathrm{~kg} / \mathrm{fed}, 150$ $\mathrm{kg} / \mathrm{fed}$ and $190 \mathrm{~kg} / \mathrm{fed}$ once a time, then incorporated into the soil to a depth of $12-20 \mathrm{~cm}$, two weeks before sowing the fruits.

Bacillus megaterium var phosphaticum was provided from the Soil Microbiology Department,Water and Environment Research Institute, Agriculture Research Center, Giza, Egypt. This strain was grown on nutrient (Difico Manual 1984) Incubated for $24 \mathrm{hr}$ at $30^{\circ} \mathrm{C}$ to obtain population of about $5 \times 10^{8} \mathrm{cFu} / \mathrm{ml}$ culture. The seeds were soaked in cell suspension of $B$. megaterium var. phosphaticum for 30 minutes before sowing. Sucrose solution (30\%) was added as an adhesive agent prior to inoculation.

The plants were sprayed with cell suspension of Bacillus megaterium 45 days of sowing

Egypt. J. Hort. Vol. 40, No.1 (2013) 
The determined growth parameters were plant height $(\mathrm{cm})$, number of branches, fresh and dry weights of aerial parts $\mathrm{g} / \mathrm{plant}$, fruit yield( $\mathrm{kg} / \mathrm{fed})$.

The oil percentage and oil yield $\mathrm{ml} /$ plant were determined as described by British Pharmacopoeia (1963). Oil composition was analyzed for some samples only (control, Egyptian Rock Phosphate (ERP at 150kg/fed and Egyptian Rock phosphate (ERP) at $150 \mathrm{~kg} /$ fed plus inoculation with phosphate dissolving bacteria (Bacillus megaterium var phosphaticum) (PDB) according to Hoftman (1967) and Bunzen et al. (1969).

The means were compared using the least significant difference (L.S.D.) test at 5\% level, as described by Little and Hills (1978).

Dehydrogenase (DHA) enzyme activity of rhizosphere area of coriander plants was determined by the method described by Thalmann (1967).

The density of phosphate dissolving bacteria was estimated by Bunt and Rovira (1955) medium, modified by, Abdel-Hafez (1966) using the plate count method.

Vegetative growth

\section{Results and Discussion}

Results presented in Table 1 showed the response of plant height, number of branches/plant and fresh and dry weights of Coriandrum sativum to Egyptian rock phosphate (ERP) and inoculation with phosphate dissolving bacteria (PDB), Bacillus megaterium var. phosphaticum.

It is obvious that growth characters of coriander plants are significantly increased due to the tested treatments in both seasons.

Regarding the effect of rock phosphate on the growth of coriander plants, data showed that all studied parameters in Table 1 gradually increased with increasing the rate of rock phosphate fertilizer up to $150 \mathrm{~kg}$ ERP/fed, which recorded 105.17 and $111.97 \mathrm{~cm}$ for plant height, 14.80 and 16.10 branches/plant, 313.28 and $355.31 \mathrm{~g}$ fresh weight and 113.21 and $126.69 \mathrm{~g}$ dry weight/ plant in the first and second season respectively. Such effect may be due to that phosphorus encourages the growth of root system and enhances the photosynthesis, carbohydrates metabolism and protein synthesis which in turn increase the amount of metabolites synthesized by plants and concequently increase dry matter of plant parts i.e. roots, leaves and stems. These results are in accordance with those reported by Venturin et al. (1995) on Hevea sp, Sharma et al. (1995) and Haque and Lupwayi (1999) on clover. Also these results are confirmed by those reported by Aly and Mowafy (2003) El-Sayed and Youssef (2003) and El- Sayed et al. (2009). 
EFFECT OF EGYPTIAN ROCK PHOSPHATE AND PHOSPHATE ...

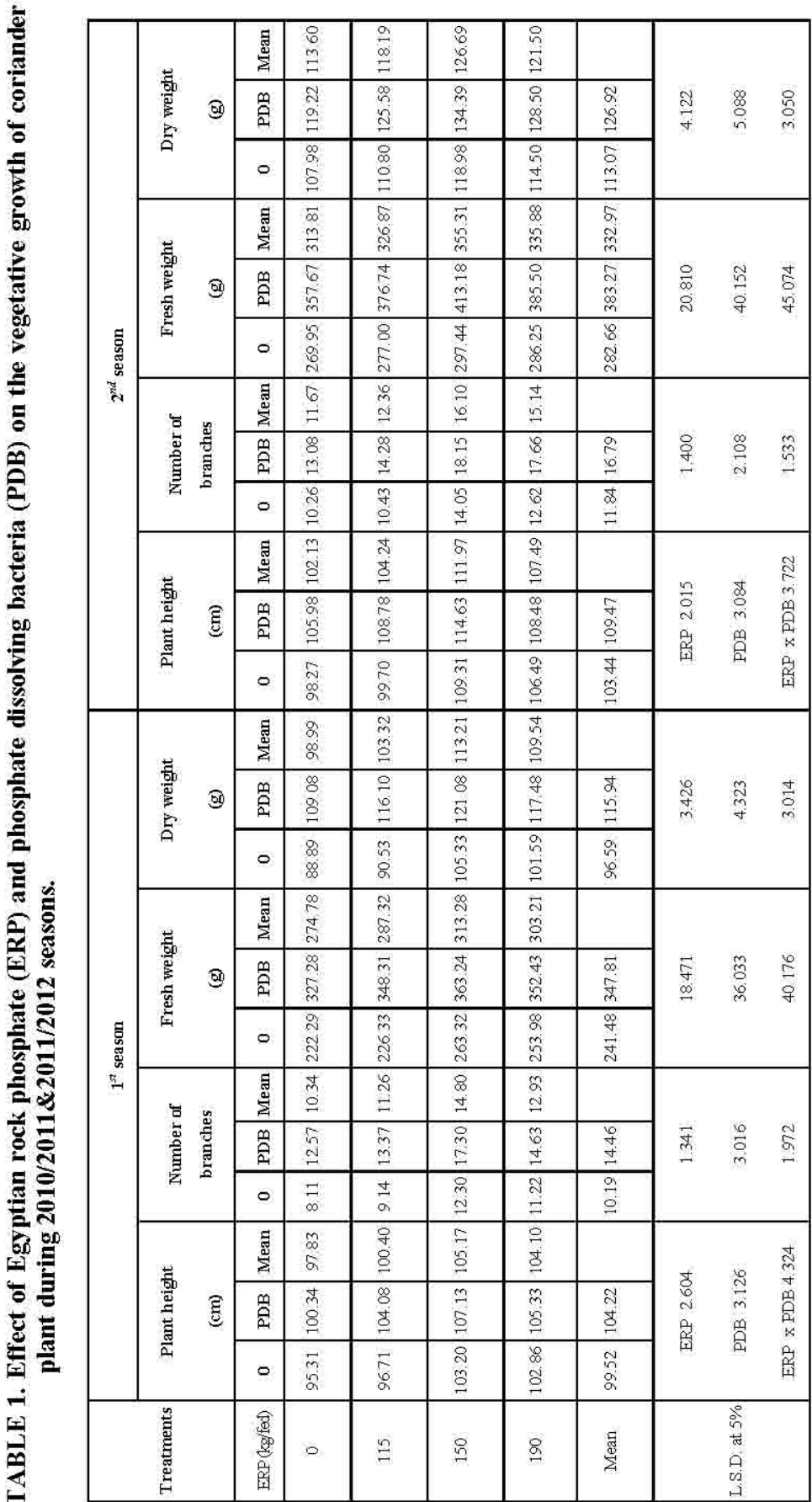

Egypt. J. Hort. Vol. 40, No.1 (2013) 
Inoculation by Bacillus megaterium led to higher values of the studied parameters which recorded 104.22 and $109.47 \mathrm{~cm}$ for plant height, 14.46 and 16.79 branches/plant, 247.81 and $383.27 \mathrm{~g}$ plant fresh weight and 115.94 and 126. $92 \mathrm{~g} /$ plant dry weight of first and second season respectively. These increments were attributed to the vital role of phosphate dissolving bacteria (Bacillus megaterium) which increased $\mathrm{P}$ uptake by plants and produce IAA and cytokinin thus it helps the plant growth promotion.

These results are in harmony with those obtained by Mekhemar et al. (2007) and Abou-Zeid et al. (2011). The reached results at uninoculated treatments were acceptable even they were lower than the other inoculated treatments, this behavior may be due to the positive role of native bacteria mainly plant growth promoting rhizobacteria (PGPR) that inhabited soil among several decades ago.

Concerning the effect of interaction between ERP and PDB, data in the same table reveal that, the application of Bacillus bacteria (PDB) combined with ERP fertilizer at (150 kg ERP/fed) resulted in the highest values of the studied growth characters which recorded 107.13 and $114.63 \mathrm{~cm}$ for plant height, 17.30 and 18.15 branches/plant, 363.24 and $413.18 \mathrm{~g}$ for plant fresh weight and 121.08 and $134.39 \mathrm{~g}$ for plant dry weight in the first and second seasons, respectively. These date are in accordance with those obtained by Malewar et al. (2000) on cotton and Mekhemar et al. (2007) on peanut.

\section{Fruit yield}

From data in Table 2, it can be noticed that treating the plants with ERP significantly increased fruit yield $\mathrm{g} / \mathrm{plant}$ and fruit yield $\mathrm{kg} / \mathrm{fed}$ over the control in both seasons.

Raising the rate of ERP from 0 to $150 \mathrm{~kg} / \mathrm{fed}$ gradually increased fruit yield/plant and fruit yield/fed in the two seasons. In the first season values were $38.03 \mathrm{~g} / \mathrm{plant}$ and $839.34 \mathrm{~kg} / \mathrm{fed}$, while in the second one, values were 39.34 $\mathrm{g} /$ plant and $874.63 \mathrm{~kg} / \mathrm{fed}$ respectively.

The positive effect of increasing phosphorus addition rates from 0 to $150 \mathrm{~kg}$ ERP/fed on coriander fruit yield may be due to the favorable effects of phosphorus in stimulating the growth of the root system, consequently increasing the efficiency of various nutrients absorbing that enhance the studied vegetative growth parameters of coriander plants, which in turn increase number of umbels and fruit yield. These results are in harmony with those obtained by El-Sayed and Youssef (2003) and El-Habbasha et al. (2005).

The results recorded in the two seasons Table 2 also showed that the inoculation with (PDB) significantly increased fruit yield/plant and fruit yield/fed. compared to control.

These results may be attributed to the nature of root exudates, which are suitable substrates for the associative bacteria, the release plant promote substances mainly indole acetic acid and cytokinins. These plant growth promoters could stimulate plant growth and the metabolism of photosynthates.

Egypt. J. Hort. Vol. 40, No.1 (2013) 
EFFECT OF EGYPTIAN ROCK PHOSPHATE AND PHOSPHATE ...

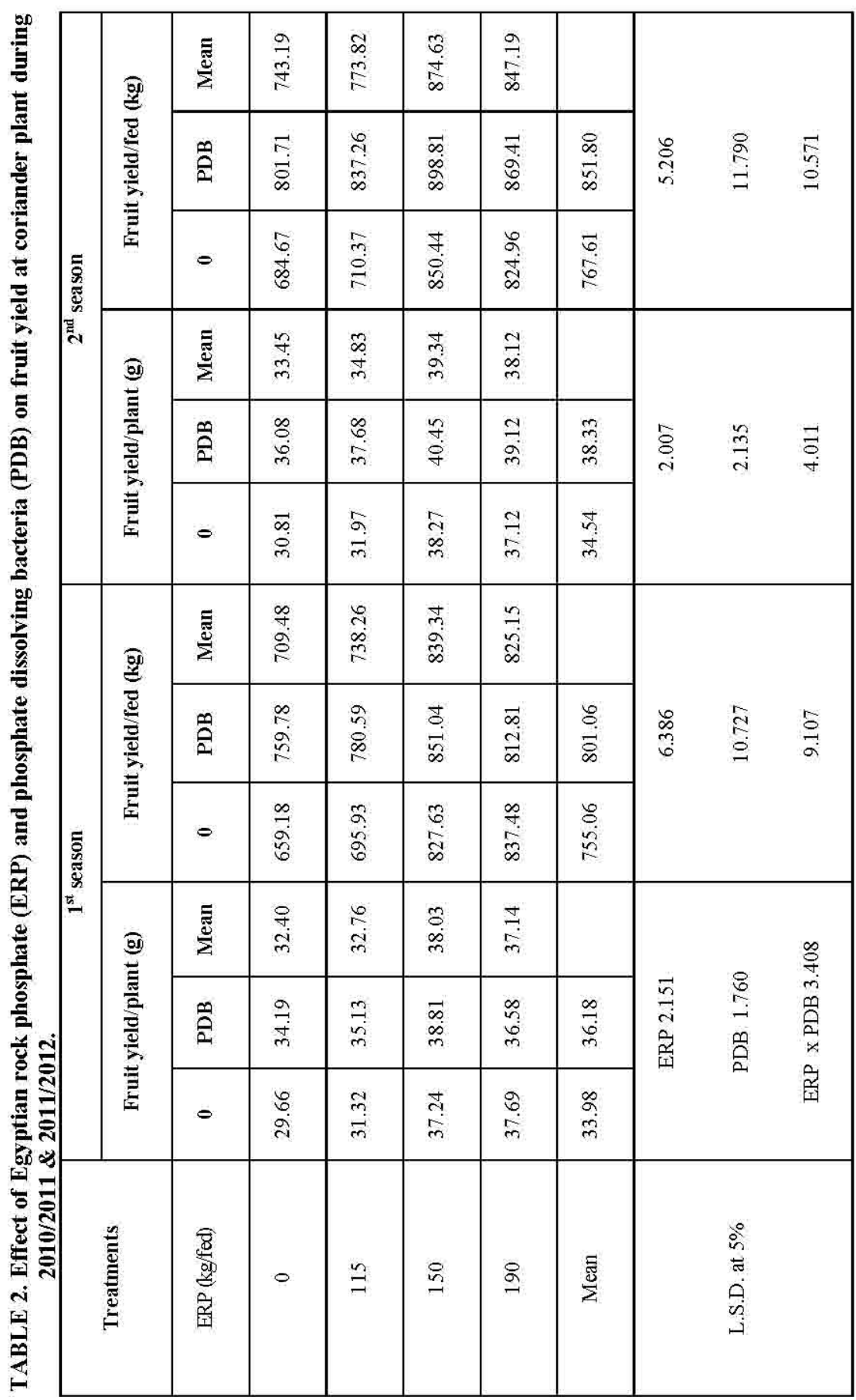

Egypt. J. Hort. Vol. 40, No.1 (2013) 
These results are stand in accordance with this reported by Tilak et al. (2005).

The interaction between (ERP) and (PDB) significantly increased fruit yield/plant and fruit yield/fed. The plants treated with (ERP) at $150 \mathrm{~kg} / \mathrm{fed}$ combined with phosphate dissolving bacteria (PDB) gave the highest fruit yield/plant and fruit yield/fed in the two seasons. The values were $38.81 \mathrm{~g} / \mathrm{plant}$ and $851.04 \mathrm{~kg} / \mathrm{fed}$ respectively in the first season and $40.45 \mathrm{~g} / \mathrm{plant}$ and 898.81 $\mathrm{kg} / \mathrm{fed}$ respectively in the second one.

\section{Oil production}

Essential oil percentage in coriander fruits, essential oil yield $\mathrm{ml} / \mathrm{plant}$ and essential oil yield liter/fed were significantly responded to ERP at different rates, PDB inoculation and their interactions as recorded in Table 3.

Regarding the effect of ERP fertilizer rates, data revealed that the treatment of $150 \mathrm{~kg}$ ERP/fed achieved the highest essential oil percentage in coriander fruits, yield/plant and yield/fed over untreated plants. These values represented 0.325 and $0.329 \%$ for essential oil percentage, while in case of essential oil/yield it was 0.124 and $0.130 \mathrm{ml} / \mathrm{plant}$ and 2.945 and $2.853 \mathrm{liter} / \mathrm{fed}$. in the first and second seasons, respectively. The enhancement of essential oil production of coriander fruits by the addition of phosphorus fertilizer may be due to the development of plant nucleoproteins, transfer of metabolite compounds and the efficiency of its root system leading to more absorbing of water and nutrients, which led to increasing the rate of physiological processes and finally gave better yields. These results are in line with those obtained by El-Sayed et al. (2009) on tarragon and Abou-Zied (2011) on soybean.

Regarding the inoculation factor, data showed that Bacillus megaterium gave the maximum values of the above mentioned parameters, these values represented 0.319 and $0.321 \%$ for essential oil percentage of fruits, 0.116 and 0.124 oil yield ml/plant and 2.539 and 2.714 liter oil/fed of first and second season, respectively.

These results are partially similar to those reported by Abou- Zeid (2011) who found that inoculation with Bacillus Bacillus polymyxa gave the highest oil yields/fed while Bacillus megaterium gave insignificant increase in oil yield of soybean.

The interaction between $\mathrm{P}$ fertilizer rates and the bacterial inoculation leds to significant increase in oil production., Results indicated that the treatment received $150 \mathrm{~kg}$ ERP/fed combined with PDB (Bacillus megaterium) gave the highest values of oil percentage, oil yield/plant and oil yield/fed for both seasons followed by plants fertilized with $190 \mathrm{~kg}$ ERP/fed combined with PDB. 
EFFECT OF EGYPTIAN ROCK PHOSPHATE AND PHOSPHATE ... 71

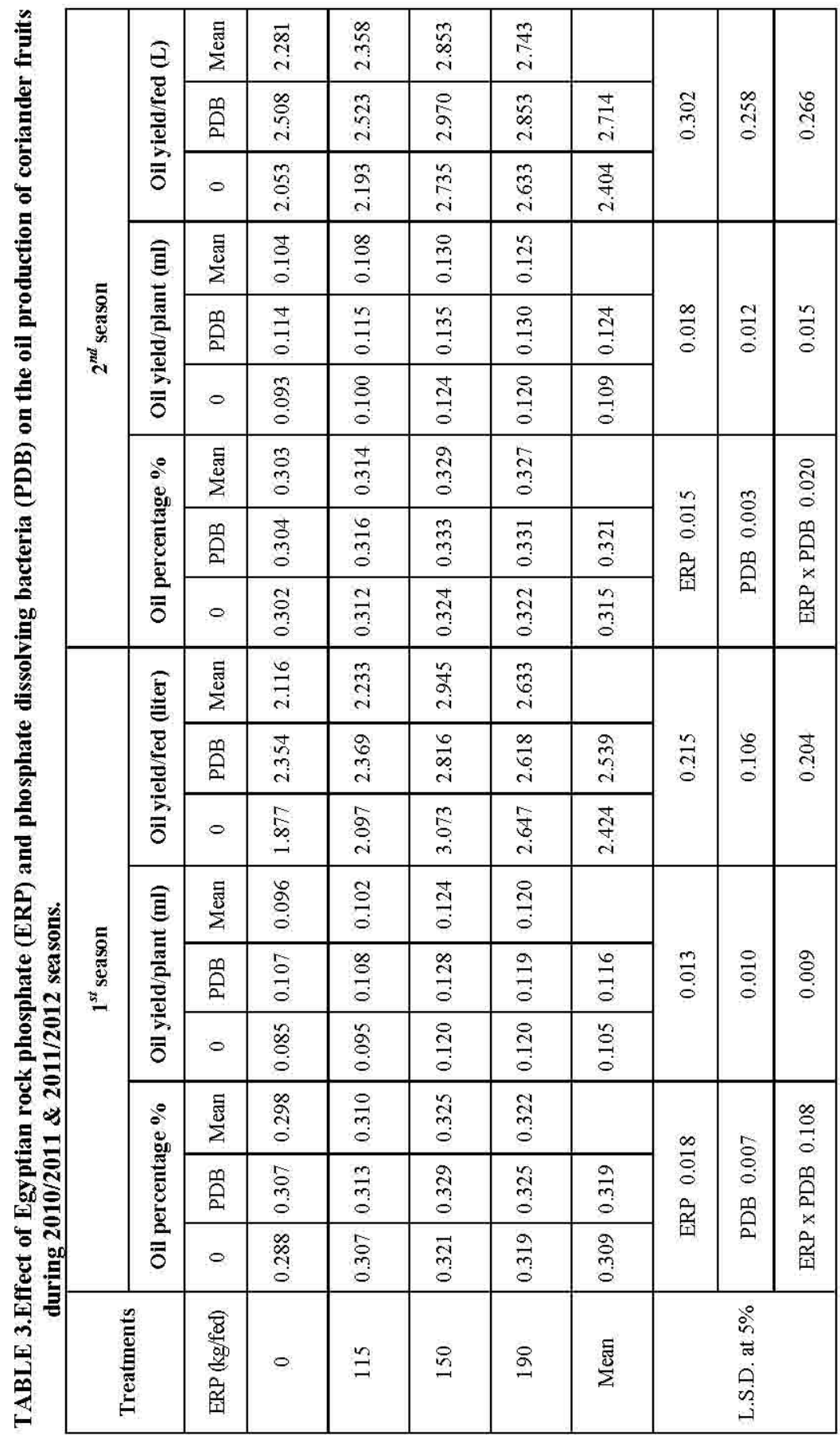

Egypt. J. Hort. Vol. 40, No.1 (2013) 
These increments in oil yield can be explained by the important role of phosphorus as an essential constituent of phospholipids (Devlin, 1975) also, their positive effects also may be due to their effects on the enzymes activity and metabolism of essential oil production Burbott and Loomis (1969). The present results are in line with those found by Badran (2003) who reported that, phosphate solubilizing microorganisms and phosphorus fertilizer on soybean and lentil plants, led to higher nutrient concentration in seeds and an increment in seed yield. The obtained increment in oil yield of coriander fruits could be explained on the light of the above mentioned results which indicated that ERP and PDB have positive effects in both coriander growth and oil production so, fruit yield was increased and the oil present was stimulated, consequently the oil yield was increased. These are in accordance with those obtained by Abd-El Kader and Ghaly (2003) on coriander, Badran and Safwat (2004) and Badran et al. (2007) on fennel plants.

\section{Chemical composition of oil}

Chromatographic analysis of oil samples extracted from coriander plant in the second season (table 4) showed that, Linalool was the main component (with content of 69.23 to $75.43 \%$ ).

The combination between ERP at $150 \mathrm{~kg} / \mathrm{fed}$ and PDB gave higher Linalool content over control (without PDB or ERP) and the plants treated with (ERP) alone.

TABLE 4. Effect of Egyptian rock phosphate (ERP) and phosphate dissolving bacteria (PDB) on the components $(\%)$ of the essential oil of coriander at 2011/2012

\begin{tabular}{|l|c|c|c|c|c|c|c|c|}
\hline Treatments & $\alpha$ pinene & Mycene & B. pinene & P. cymene & Linalool & Geroniol & Lenalyl & Nerol \\
acetate & & & & & & \\
\hline Control & 4.46 & 1.06 & 2.99 & 6.88 & 69.23 & 3.92 & 4.18 & 4.19 \\
\hline $\begin{array}{l}\text { ERP without } \\
150 \mathrm{~kg} / \mathrm{fed}(\mathrm{PDB})\end{array}$ & 4.02 & 1.11 & 2.96 & 6.25 & 70.41 & 6.25 & 2.88 & 3.01 \\
\hline $\begin{array}{l}\text { ERP 150kg/fed + } \\
\text { PDB }\end{array}$ & 3.43 & 1.14 & 2.65 & 5.41 & 75.43 & 5.62 & 3.16 & 1.87 \\
\hline
\end{tabular}

Egypt. J. Hort. Vol. 40, No.1 (2013) 


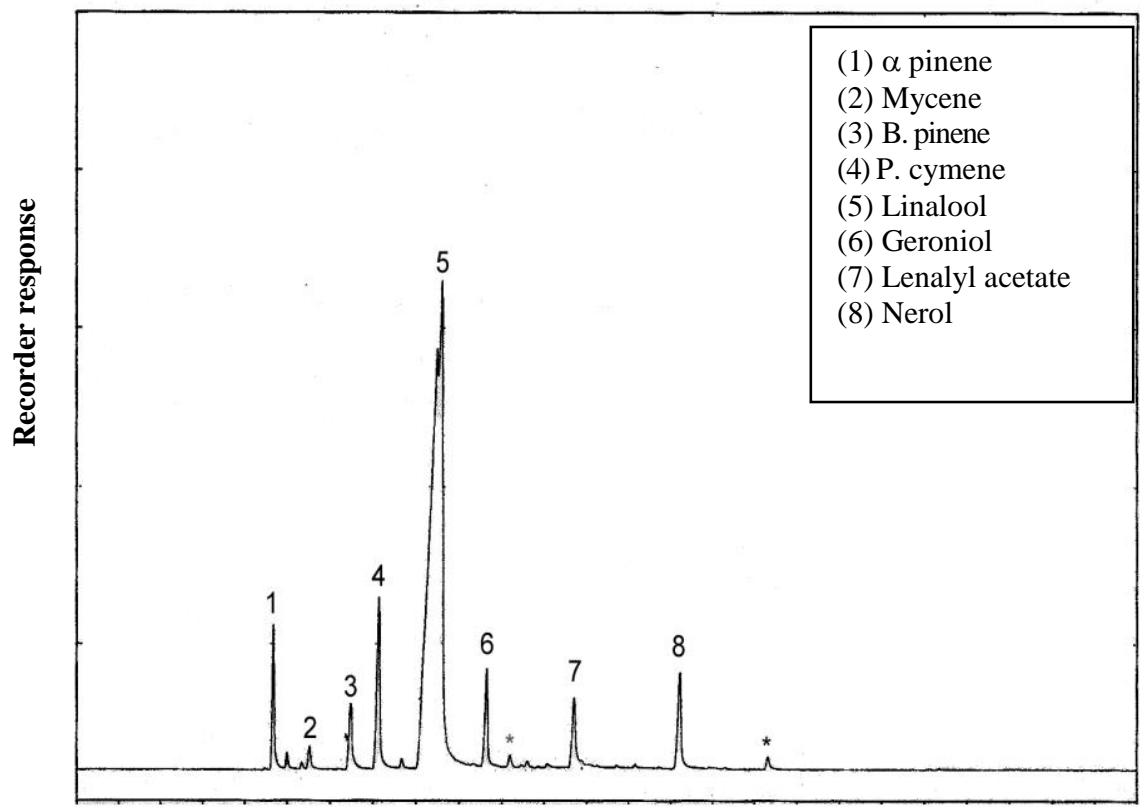

Retention time (min)

Fig. 1. GLC chromatogram of coriander oil (Control)

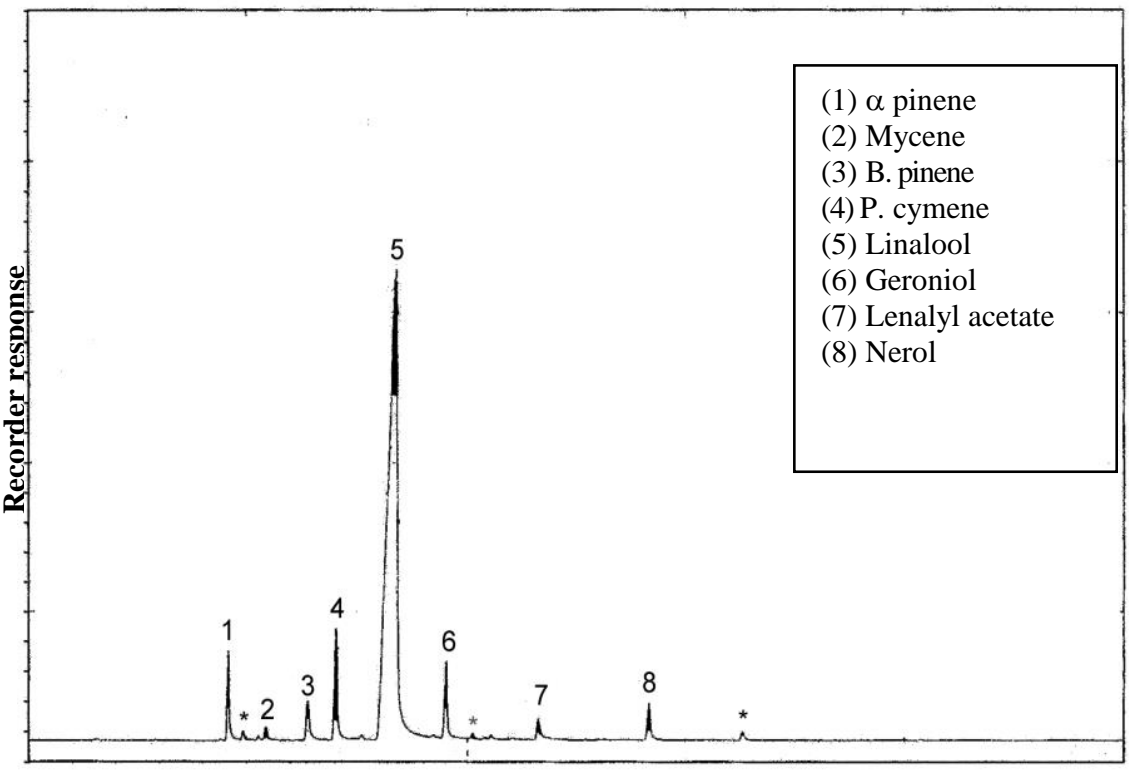

Retention time (min)

Fig. 2. GLC chromatogram of coriander oil (ERP at $150 \mathrm{~kg} / \mathrm{fed}$ without PDB)

Egypt. J. Hort. Vol. 40, No.1 (2013) 


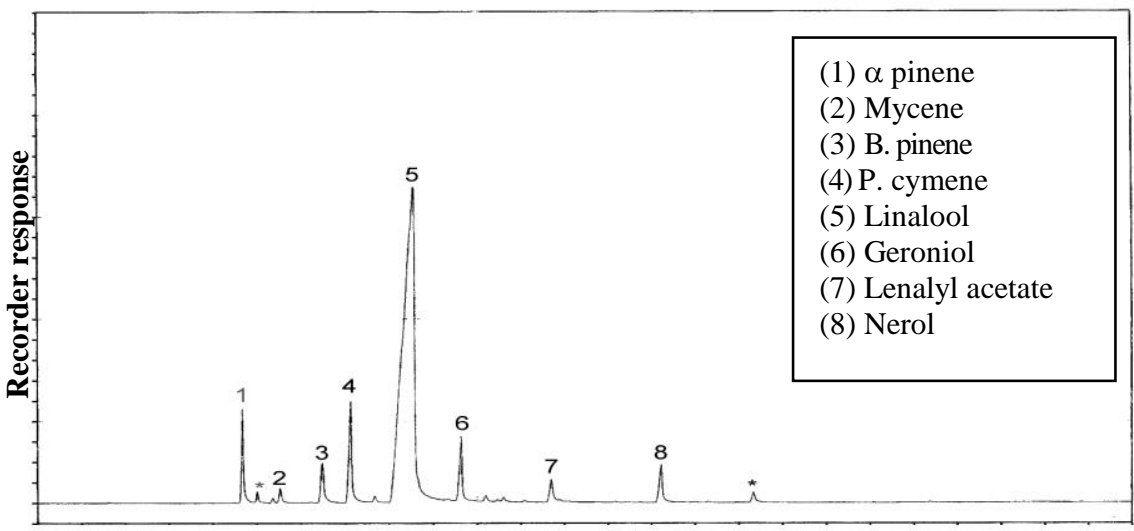

Retention time (min)

Fig. 3. GLC chromatogram of coriander oil (ERP at $150 \mathrm{~kg} / \mathrm{fed}$ plus PDB)

Phosphate dissolving bacteria (PDB) count

Data illustrated in Fig. 4 and 5 showed the Changes of dehydrogenase enzyme activity and Bacillus megaterium count in the rhizosphere of treated plant.

Regarding dehydrogenase enzyme activity (DHA), data in Fig. 4 revealed that, inoculated treatments gave values of DHA higher than those of untreated treatments in both seasons. Also, these values were increased with increasing rock phosphate up to $150 \mathrm{~kg} / \mathrm{fed}$ the highest values were 95.74 and $86.88 \mu \mathrm{g}$ triphenyl formazan (TPF)/g dry soil/day when the plant inoculated with Bacillus megaterium and fertilized with $150 \mathrm{~kg}$ rock phosphate/fed. This diversity of DHA activity among the treatments indicate a change in the composition and activity of soil microorganisms.In the respect dehydrogenase enzyme which is only present in viable cells, has been considered as a sensitive indicator of soil quality and it has been proposed as a valid biomarker to indicate changes in total microbial activity due to soil management (Roldan et al. 2004). The present data confirmed the previous findings showing an increase in dehydrogenase activity. These results are in harmony with those of Abou- Zeid (2011) who found that, dehydrogenase activity of plant rhizosphere significantly increased as a result of bacillus inoculation and phosphorus fertilizer.

With respect to the count of phosphate dissolving bacteria, Fig. 4 showed that microbial density of abovementioned bacteria group gradually increased with the increasing of Egyptian rock phosphate (ERP) up to $150 \mathrm{~kg} / \mathrm{fed}$. These maximum log numbers represented 7.176 and 7.230 for inoculated treatments and 6.752 and 6.778 for uninoculated treatments in the first and second seasons, respectively. These notable increases indicated that the bacterial numbers positively influenced by the plant root exudates and surplus of nutrients. This could be due to the mode of action of the applied bacteria, which not only provide soluble phosphorus, by producing organic acids but also produce a variety of growth promoting substances. These substances stimulate the production of root exudates, which in turn affect their numbers and the number of native bacteria.

Egypt. J. Hort. Vol. 40, No.1 (2013) 


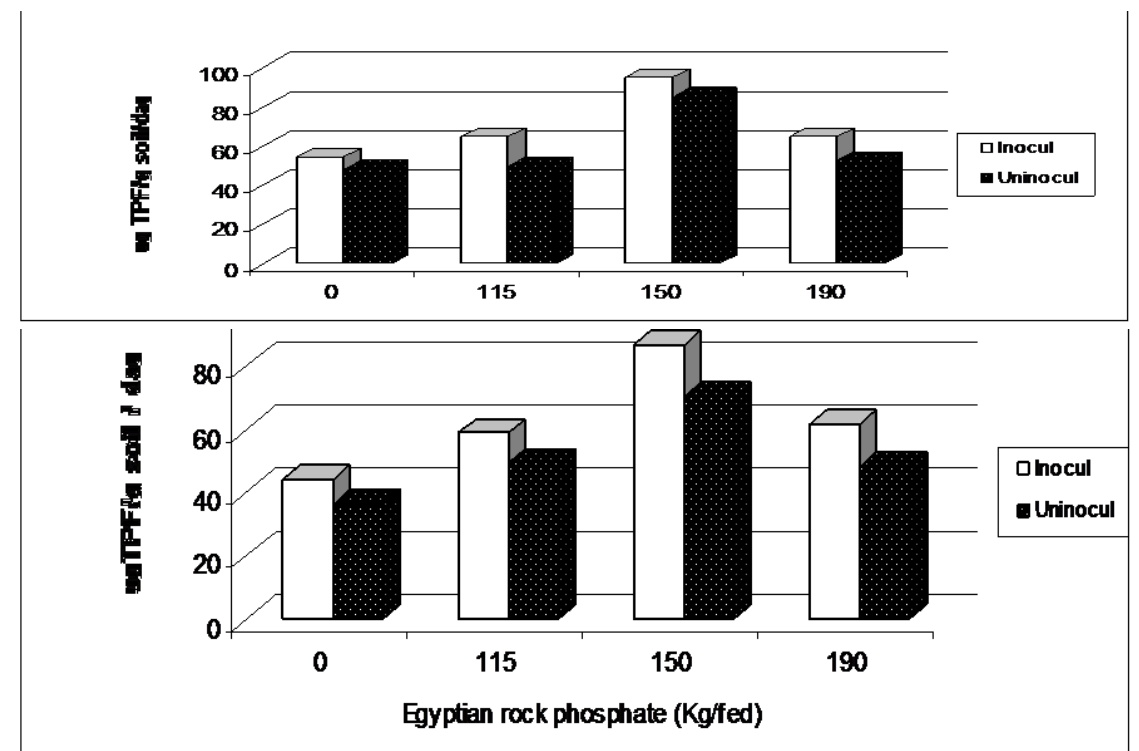

Fig. 4. Effect of ERP and B. Megaterium on dehydrogenase enzyme activity in the rhizosphere of Coriandum sativum (The first season)
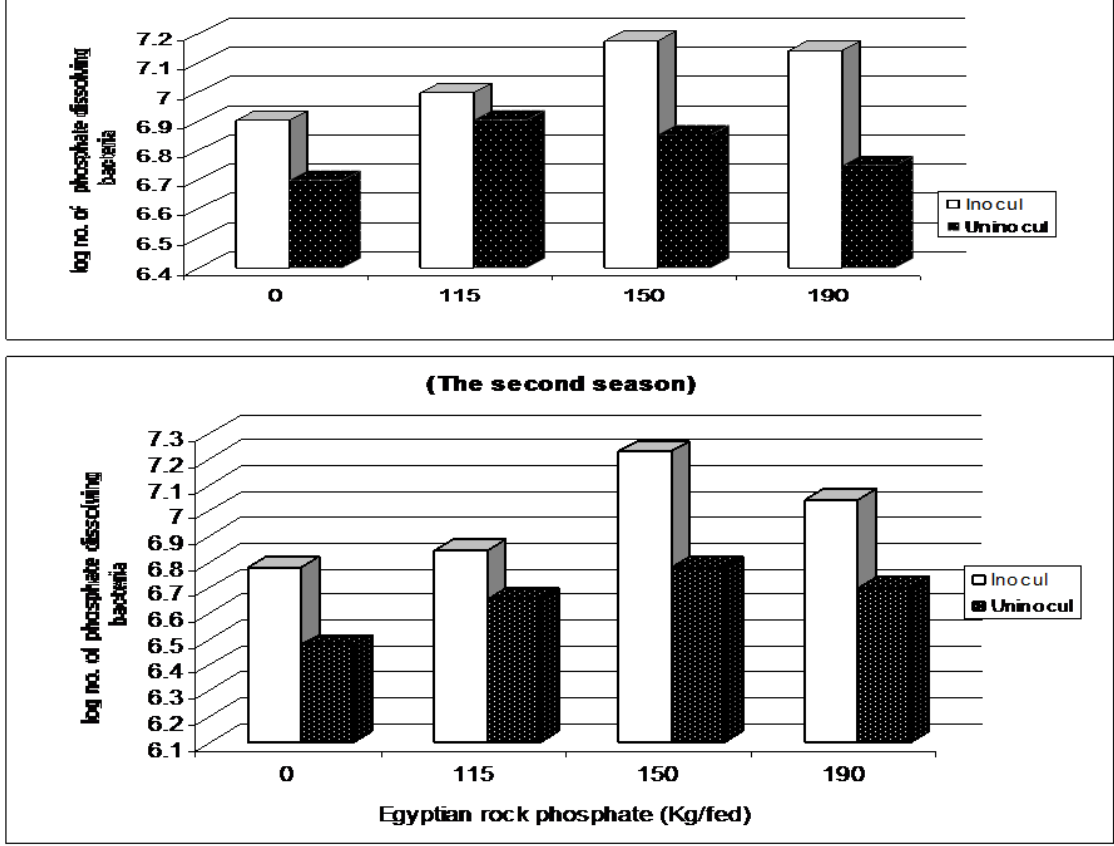

Fig. 5. Effect of Egyptian rock phosphate and $B$. megaterium bacteria on log number of phosphate dissolving bacteria in the rhizosphere of Coriandum sativum (The first season) 
Similar results were obtained by Abdel-Ati et al. (1996) and Saleh et al. (1998). The reached results at uninoculated treatments were acceptable even they were lower than the other inoculated ones, this behavior could be due the positive role of native bacteria inhabiting soil among several decades ago.

\section{References}

Abdel-Ati, Y.Y., Hammad, A.M. and M.Z. Ali, (1996) Nitrogen fixing and phosphate dissolving bacteria as biofertilizers for potato plants under Mini conditions. $1^{s t}$. Egyptian Hangarian Horticultural Conf., Kafr El-Sheikh, Egypt., 25-34.

Abdel-Hafez, A.M. (1966) Some studies on acid production producing microorganisms in soil and rhizosphere with special reference to phosphate dissolving. Ph.D. Thesis, Agric. Botany Dept. Fac. Agric., Ain Shams Univ., Egypt.

Abd-ElKader, H.H. and Ghaly, N.G. (2003) Effect of cutting the herb and the use of nitrobein and phosphorein associated with mineral fertilizers on growth, fruit and oil yield and chemical composition of the essential oil of coriander plants (Coriandrum sativum) J. Agric. Sci. Mansoura Univ., 28 (30), 2161-2171.

Abou-Zied, M.Y. (2011) Improvement of soybean growth by co-inoculation with Rhizobium and plant growth promoting rhizobacteria, Egypt J. Appl. Sci., 26 (11), 445-459.

Ahmed, Kh.A., Madiha M. Badran, and Samia H. Ashmawy, (2002) Response of soybean to chemical and bio-fertilization. Egypt. J. Appl. Sci., 17, 207-218.

Aly, A.A.G. and Mowafy, S.A.E. (2003) Effect of different levels of potassium and phosphorus fertilizers with the foliar application of zinc and boron on peanut in sandy soils. Zagazig. J. Agric. Res., 30, 335-358.

Badran, Madiha M. (2003) Effect of nitrogenous and phosphatic fertilization on some economical characters of soybean Crawford cultivar under calcareous soil conditions. Egypt. J. Agric. Res., 81, 433-439.

Badran, F.S. and M.S. Safwat, (2004) Response of Fennel plants to organic manure and biofertilizers in replacement of chemical fertilization Sec. International Conf. of Organic Agric. Cairo, Egypt, March.

Badran, F.S., Nadia M. Abdalla., Ali, M.K. and Soad M. Ibrahim, (2007) Response of fennel plants to seeding rate and partial (replacement of mineral NPK by biofertilization treatments. African Crop Sci. Conf. Proc., 8, 417-422.

British Pharmacopoeia (1963) Determination of Volatile Oils in Drugs. The Pharmaceutical Press, 17 Bloomsbury Square, London, WCL. 220-222.

Bunt, J.S. and Rovira, A.D. (1955) Microbiological studied of some subantactic soils. Journal of Soil Sci., 6, 114-128.

Egypt. J. Hort. Vol. 40, No.1 (2013) 
Bunzen, J.N., Guichar, J., Labbe, P. Prevot, J. Seprpinet, J. and Tranchant, J. (1969) Practical Manual of Gas Chromatography Journal Tranchant, Ed., El-Seivier Publ. Co., Amesterdam-London, 189-206.

Burbott, A.J. and Loomis, D. (1969) Evidence for metabolic turnover monoterpene in peppermint. Plant Physiology, 44, 173-179.

Chakrabotry, U., Chakarbotry, B. and Basnet, M. (2006) Plant growth promotion and induction of resistance in camellia sinensis by Bacillus megaterium. J. Basic Microbiology. 46, 186-195.

Devlin, R.M. (1975) Plant Physiology, $3^{\text {nd }}$ ed. Affiliated East. West Press Pvt. Ltd., New Delhi.

Difico Manual (1984) Dehydrated Culture Media and Reagents for Microbiology. $10^{\text {th }}$ ed. Difico Laboratories, Detroit Michigan, 48232. USA. p. 6, 21.

El-Habbasha, S.F., Kandil, A.A., Abu Hagaza, N.S. Abd El- Haleem, A.K. Kalafallah, M.A. and Behairy, T. Gh. (2005) Effect of phosphorus levels and some biofertilizers on dry matter, yield and yield attributes of groundnut. Bull. Fac. Agric. Cairo Univ., 26, 237-252.

El-Sayed, A.A. (2006) Effect of some Agricultural practices on anise plants. Minia J. Agric. Res. \& Develop., 28 (2), 297-308.

El-Sayed, A.A., Mahassen, M.A. Sidky., Mansour, H.A. and Mai M.A. Mohsen, (2009). Effect of organic fertilizer and Egyptian rock phosphate on the growth, chemical composition and oil production of Tarragon (Artemisia dracunculus, L) $\mathrm{J}$. Product \& Dev., 14 (1), 87-110.

El-Sayed, M.A.A. and Youssef, H.Y.M. (2003) Effect of phosphorus fertilizer rates on peanut productivity under some irrigation intervals in sandy soil. Egypt. J. Appl. Sci., 18, 184-199.

Espinnosa, L.E., Sanchg, C.A. and Schueneman, T.J. (1993) Celery yield respond to potassium rate, Horticultural Sciences, 28, 1125-1128.

Grham, J.F. and Timmer, L.W. (1985) Rock phosphate as a source of phosphorus for vesicular arbscular Mycorrhizal development and growth of citrus. J. Amer. Soc., Hort. Sci., 110 (4), 489-492.

Haque, I. and Lupmayi, N.Z. (1999) Responses of clover and desmodium to Egyptian rock phosphate in Ethiopia. Tropical Agriculture, 76 (17), 109-113.

Hikal, M.E. and Omar, A.A. (1993) Medicinal and Aromatic Plants, Published by Manshate El-Maaref, Alex, Egypt, pp 204, 274-281.

Hoftman, E. (1967) Chromatography. $2^{\text {nd }}$ ed., Reinhold Publ. Corp. 208-515.

Kloepper, J.W. and Schroth, M.N. (1981) Plant growth promoting rhizobacteria and plant growth under genobiotic conditions. Phytopathology, 71, 642-644. 
Little, T.M. and Hills, F.J. (1978) Agricultural Experimenation-Design and Analysis. John Wiley and Sons, Inc., 53-60, 63-56.

Mahran, G.H. (1967) Medicinal Plants. $1^{\text {st }}$ ed., Cairo, Anglo Egyptian Bookshop. pp 396397.

Malewar, G.U., Rege, V.S., Yelvikar, N.V. and Ismail, S. (2000) Influence of various levels and sources of phosphorus on yield and attributing characters of phosphorus on yield and attributing characters of irrigated cotton (Gossypium hirsutumL.). Annals Agric. Res., 21(4), 577-579.

Mekhemar, G.A.A., Ismail, F.M., Badawi, F.Sh.F. and Kandil, B.A.A. (2007) Response of peanut (Arachis hypogeaa) to Co. inoculation with Bradyrhizobium spp. and phosphate dissolving bacteria under different level of phosphorus fertilization in sandy soils. Agric. Res. J. Suez Canal Univ., 7(1), 1-8.

Roldan, A., Salinas-Garcia, J.R. Alguacil., M.M., Diaz, G. and Caravaca, F. (2004) Changes in soil microbial activity following conservation tillage practices in a sorghum field under subtropical conditions $13^{\text {th }}$ International Soil Conservation Organization Conference Brisbane.

Saleh, S.A., Nokhal., T.H., El-Borollosy, M.A., Fendrik, I., Sharaf, M.S. and Sawy, M. (1998) Effectiveness of dual inoculation with diazotrophs and vesicular arbusular mycorrhizae on growth and medicinal compound of Datura stramonium. Arab Univ. Journal Agric. Sci. Ain Shams, Univ., Cairo, 62, 343-355.

Sastry, K.P., Kumar, D., Saleem, S.M. and Radhakrishnan, K. (1997) Effect of phosphorus on growth of pyrethrum plants (Chrysanthemum cinerariaefolium) and on flower yields. Pyrethrum Post, 19 (8),132-138.

Sharma, D.K., Sharma, K.L., Sharma, C.M. and Bhardmaj, S.K. (1995) Effect of different phosphorus sources on yield and quality of tea (Camellia Sinensis) in a hill acid soil. Indian J. Agric. Sci., 65(9), 574-577.

Thalmann, A. (1967) Uber die microbiella aktivitat undihr benziehungzu frucht-bat kettes markmalen einiger acherboden unter besonderer beruksi chtigung der Dehydrogenase aktivitat (TTC. Reduktion). Biss, Gieben. Ph.D. Thesis, W. Germany.

Tilak, K.V., Ranganayaki, B.R., Pal, N., De., K.K., Sarena, R., Shekhar, A.K., Nautriyal, C., Shilpi Mittal, Tripathi, A.K. and Tohri, B.M. (2005). Diversity of plant growth and soil health supporting bacteria. Current, Sci., 89, 136-150.

Venturin, N., Nogueira, F.D. and Coqueiro, G.R. (1995) Effect of Araxa rock phosphate, Lime and gypsum on rubber (Hevea sp.) seedlings. Pesquisa Agropecuaria Brasileira, 30 (20), 187-193.

Zayed, G. (1998) Can the encapsulation system protect the useful bacteria against their bacteriophages. Plant and Soil, 197, 1-7.

(Received 11/2/ 2013 ; accepted 18 / 4/ 2013) 

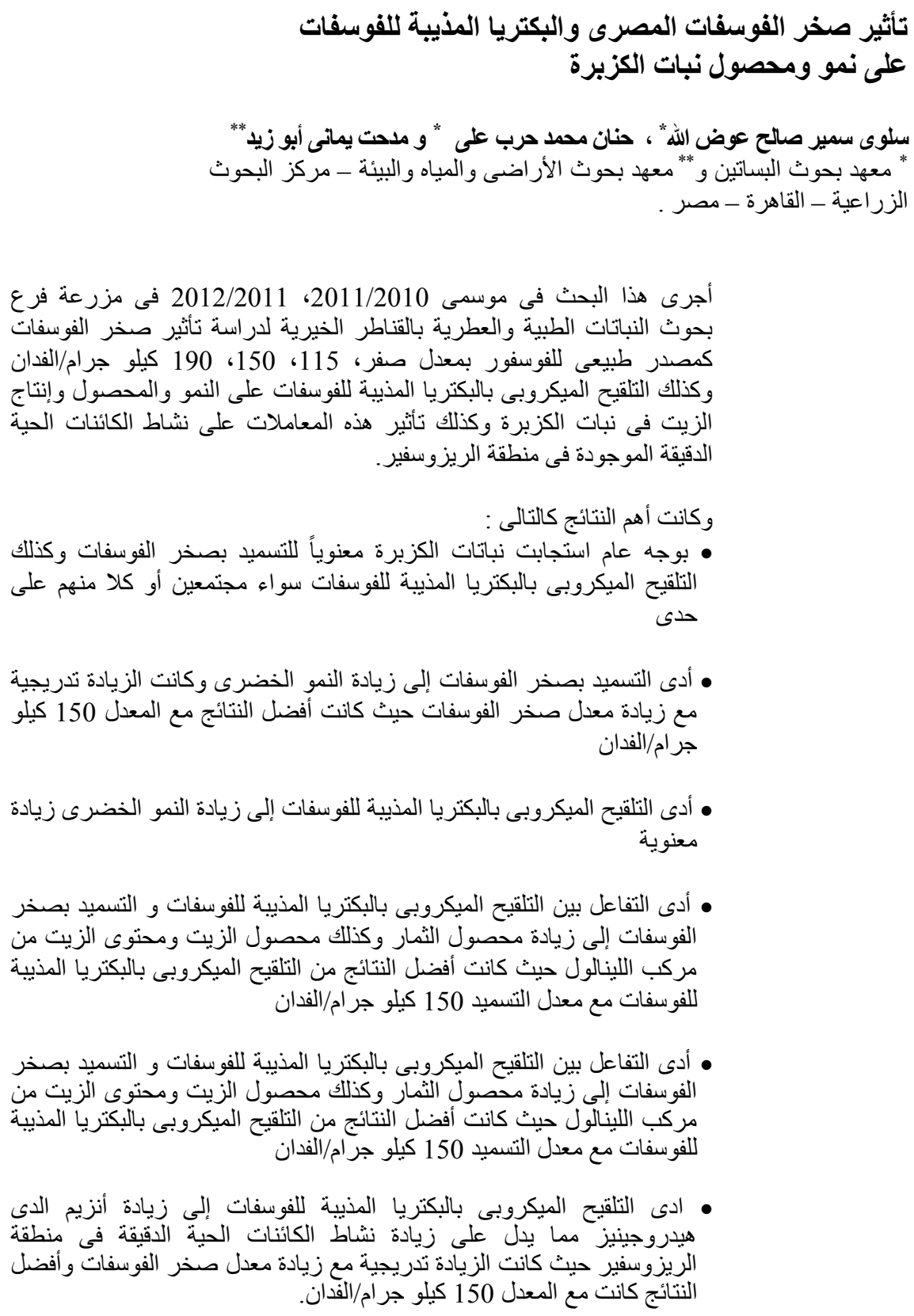